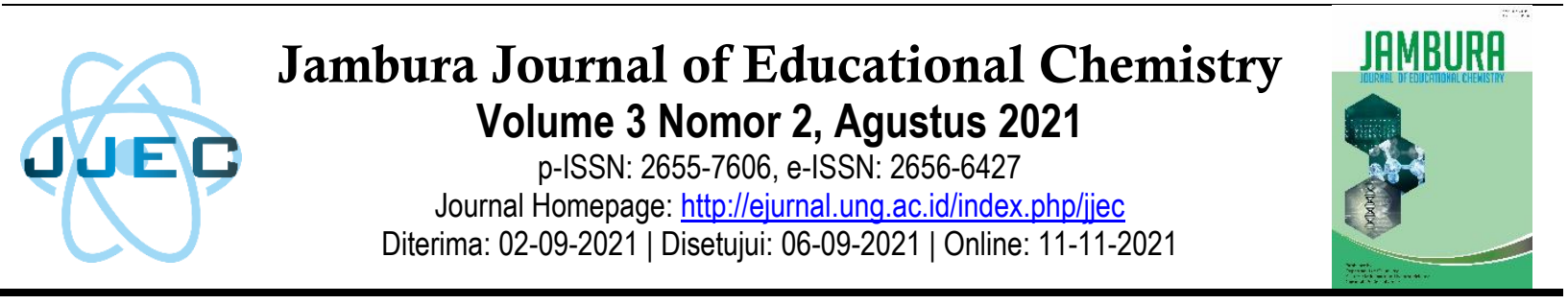

\title{
Pengembangan Video Animasi Kimia Terintegrasi Keislaman Pada Materi Struktur Atom
}

\author{
Buchori Muslim', Munasprianto Ramli², dan Ulfah Nursarifah ${ }^{3}$ \\ 1,3Prodi Pendidikan Kimia, Fakultas FITK, Universitas Islam Negeri Syarif Hidayatullah, \\ Ciputat, Tangerang Selatan, 15412, Indonesia \\ 2Prodi Pendidikan Kimia, Fakultas FITK, Universitas Islam Negeri Syarif Hidayatullah, \\ Ciputat, Tangerang Selatan, 15412, Indonesia \\ e-mail: ${ }^{1}$ buchorimuslim@uinjkt.ac.id
}

\begin{abstract}
Abstrak
Penelitian ini bertujuan untuk menghasilkan suatu produk media pembelajaran berupa video animasi kimia terintegrasi keislaman pada materi struktur atom. Proses pengembangan dalam penelitian ini menggunakan model ADDIE yang terdiri dari dari analyze (analisis), design (perancangan), development (pengembangan), implementation (implementasi), dan evaluation (evaluasi). Hasil penelitian uji coba terbatas kepada mahasiswa diantaranya aspek minat terhadap media dengan presentase $84 \%$, aspek penguasaan materi dengan presentase $83,30 \%$, aspek integrasi sains dan islam dengan presentase $86,4 \%$, aspek tampilan dengan presentase $83 \%$, aspek keterlaksanaan dengan presentase $84,7 \%$, serta aspek audio dengan presentase $84,1 \%$. Sehingga secara keseluruhan uji coba terbatas kepada mahasiswa mendapatkan presentase $84,30 \%$ dengan kriteria sangat layak. Hasil penilaian produk video animasi oleh ahli media sebesar $82,50 \%$ untuk video $1,83,75 \%$ untuk video 2 , dan $82,50 \%$ untuk video 3 . Sehingga video animasi yang dikembangkan dalam penelitian ini mendapat kriteria sangat layak.
\end{abstract}

Kata kunci: Integrasi Keislaman, Struktur Atom, Video Animasi.

\section{PENDAHULUAN}

Pendidikan adalah sumber daya yang signifikan dan roda menuju perubahan bagi keberadaan manusia. Pendidikan juga dapat menjadi tolak ukur atau penentu kemajuan suatu negara. Dengan cara ini, pendidikan memiliki alasan khusus untuk menumbuhkan kemampuan siswa. Rencana atau perangkat untuk mencapai tujuan Pendidikan dikenal sebagai kurikulum.

Pendidikan secara konsisten mengajukan upaya yang berbeda untuk mengembangkan kurikulum di tingkat yang berbeda. Program pendidikan ini tidak hanya terbatas pada sekolah menengah, namun perguruan tinggi juga memanfaatkan kurikulum dalam sistem pembelajaran. Perguruan tinggi memiliki acuan dalam membina suatu program Pendidikan. Acuan yang diikuti perguruan tinggi dalam membina program pendidikan adalah Kerangka Kualifikasi Nasional Indonesia (KKNI). KKNI ini tertuang dalam Permenristekdikti Nomor 44 Tahun 2015 tentang Standar Nasional Pendidikan Tinggi (SNPT). Rancangan instruksi yang mengacu pada KKNI dapat dibuat dengan menentukan capaian belajar atau Learning Outcomes (LO) pada setiap jurusan di perguruan tinggi.

Salah satu capaian pembelajaran di Perguruan Tinggi Islam adalah integrasi islam di setiap bidang ilmu. Integrasi sains dan islam terjadi ketika ada titik temu antara wilayah sains dan islam (Arifudin, 2017). Bangsa akan maju dan menjadi norma kemajuan jika masyarakatnya mengenyam pendidikan yang jauh jangkauannya, yaitu pendidikan khusus yang menggabungkan ilmu 
agama dan ilmu pengetahuan terkini, bukan pengajaran yang hanya menyoroti ilmu pengetahuan masa kini dan meninggalkan pelajaran agama. Sebagaimana ditunjukkan oleh Mas'ud (2020) jika seorang peneliti mendalami ilmu pengetahuan terintegrasi islam, ia akan memperoleh kecerdasan sebagai kualitas yang luar biasa. Contoh perguruan tinggi asing yang mengoordinasikan integrasi adalah Universitas Al-Qalam. Universitas Al-Qalam adalah perguruan tinggi Islam di Katsina, Nigeria Utara. Perguruan tinggi ini mencoba memasukkan pelajaran agama islam ke dalam materi pembelajaran (Ladan, 2015).

Materi pembelajaran adalah materi yang diidentikkan dengan informasi yang sengaja disusun berdasarkan kapasitas yang harus dikuasai siswa dalam pembelajaran. Materi pembelajaran dapat dituangkan dalam sebuah media pembelajaran. Menurut Suardika (2016) video pembelajaran merupakan media umum yang di dalamnya terdapat pesan-pesan pembelajaran yang memadukan prinsip, pemikiran, strategi, dan teori aplikasi untuk membangun pemahaman yang lebih mendalam terhadap suatu materi pembelajaran. Salah satu atribut video pembelajaran adalah animasi. Animasi adalah rangkaian gambar dan tulisan yang disertai dengan gerakan (Anggriani, 2019). Menurut Al Farizi et al., (2019) animasi digunakan dalam media pembelajaran dikarenakan dua hal, yaitu untuk menarik perhatian dan memperkuat motivasi. Video animasi bisa menampilkan materi yang abstrak menjadi lebih nyata (Kusuma et al., 2021).

Materi yang abstrak dalam pelajaran kimia salah satunya adalah struktur atom. Struktur atom ini tidak bisa diilihat langsung oleh kasat mata. Nama atom berasal dari a-tomos yang dalam Bahasa Yunani berarti tidak dapat dibagi (Brady, 1999). Konsep atom dijelaskan pertama kali oleh Demokritus yang menjelaskan bahwa segala sesuatu dapat dipisahkan menjadi materi yang paling kecil sehingga dinamakan Atom (Ghalib, 2009). Konsep atom sudah terlebih dahulu Allah cantumkan didalam Alqur'an surah al-zalzalah ayat 7-8:

$$
\text { فمن يعمل مثقال ذرة خير ا بره, ومن يعمل مثقال ذرة }
$$

Artinya: "7. Barangsiapa yang mengerjakan kebaikan seberat dzarrahpun, niscaya dia akan melihat balasannya. 8. Dan barangsiapa yang mengerjakan kejahatan sebesar dzarrahpun niscaya dia akan melihat balasannya pula" (Q.S AlZalzalah: 7-8).

Ayat tersebut menjelaskan tentang keadilan. Dihari kiamat tidak akan ada kedzaliman oleh Allah bahkan hingga seberat atom yang kecil. Dihari kiamat, amalan kita akan ditimbang sampai ke satuan atom, sehingga tidak ada ketidak adilan sekecil apapun dihari itu. Menurut Sabarni (2019) menjelaskan bahwa istilah dzarrah sudah lama digunakan oleh para ahli fisika di Arab untuk menyebutkan kata atom.

Ketidakcukupan materi ajar yang terintegrasi islam terhadap materi struktur atom menunjukkan bahwa integrasi antara islam dan sains belum belum maksimal, khususnya dalam materi struktur atom. Seperti yang ditunjukkan oleh Arsanti (2018) tidak lengkapnya bahan ajar bisa mempengaruhi kualitas pembelajaran dalam suatu perkuliahan. Pengembangan video animasi terintegrasi keislaman merupakan salah satu sudut pandang yang dapat membantu memperluas informasi mahasiswa tentang integrasi. Penelitian ini bertujuan untuk menghasilkan suatu produk berupa video animasi kimia terintegrasi keislaman. Pengembangan produk berupa video animasi terintegrasi keislaman ini bisa melatih kemampuan mahasiswa dalam mengembangkan video animasi juga mendapatkan pengetahuan tambahan berupa kimia terintegrasi keislaman pada materi struktur atom bagi penontonnya.

\section{METODE PENELITIAN Jenis Penelitian}

Penelitian ini menggunakan pendekatan Reseach \& Development (R\&D) yang bertujuan untuk mengembangkan suatu produk. Menurut Arikunto (2014) Reseach \& Development merupakan suatu penelitian untuk menghasilkan produk.

\section{Waktu dan Tempat Penelitian}

Penelitian ini dilaksanakan pada Maret 2021 - Agustus 2021. Tempat penelitian 
dilaksanakan di Universitas Islam Negeri Syarif Hidayatullah Jakarta.

\section{Target/Subjek Penelitian}

Subjek dari penelitian ini adalah sebagai berikut:

1. Tiga dosen ahli materi kimia dan dua dosen ahli integrasi keislaman yang akan memvalidasi materi kimia terintegrasi keislaman dan storyboard video.

2. Dua dosen ahli media yang akan memberikan kelayakan penilaian video animasi kimia terintegrasi keislaman pada materi struktur atom.

3. Mahasiswa/I pendidikan kimia UIN Syarif Hidayatullah Jakarta

\section{Prosedur}

Penelitian ini menggunakan model ADDIE yang terdiri dari analyze (analisis), design (perancangan), development (pengembangan), implementation (implementasi), dan evaluation (evaluasi). Metode yang digunakan dalam penelitian ini adalah metode Tipe Buchori.

\section{Data, Intrumen, dan Teknik Pengumpulan Data}

Instrumen yang digunakan dalam penelitian ini berjumlah 6 instrumen; Instrumen angket analisis kebutuhan; instrumen lembar validasi materi struktur atom terintegrasi keislaman; instrumen lembar validasi storyboard video, instrumen lembar validasi angket respon mahasiswa; instrumen lembar validasi media dan instrumen angket respon mahasiswa. Teknik pengumpulan data dengan penyebaran angket.

\section{Teknik Analisis Data}

Analisis data yang diperoleh dari hasil angket analisis kebutuhan dihitung dengan mencari presentase setiap butir pernyataan dengan rumus berikut:

$$
\mathrm{P}=\frac{\text { Jumlah Siswa yang menjawab }}{\text { Total Jumlah Siswa }} \times 100 \%
$$

Keterangan:

P : Presentase setiap butir pernyataan (Rohman, 2015).

Analisis data hasil validasi materi terintegrasi keislaman dan validasi angket respon mahasiswa dilakukan dengan menggunakan skala guttman.

$\%$ Hasil Validasi $=\frac{\text { Skor Total }}{\text { Skor Maksimum }} \times 100 \%$
(Sakai, 2017). Untuk validasi materi struktur atom terintegrasi keislaman setelah melakukan penskoran dengan skala guttman selanjutnya mencari nilai Content Validity Ratio (CVR) dengan menggunakan rumus:

$$
C V R=\frac{n-\frac{N}{2}}{\frac{N}{2}}
$$

(Lawshe, 1975).

Analisis data hasil validasi storyboard video dan data hasil angket respon mahasiswa dalam penelitian ini menggunakan skala Likert. $\mathrm{P}=\frac{\text { Jumlah skor hasil pengumpulan data }}{\text { Jumlah skor kriterium }} \times 100 \%$

Keterangan:

Skor Kriterium $=$ skor tertinggi tiap butir $\mathrm{x}$ jumlah butir x jumlah responden

$\mathrm{P}=$ Presentase kesesuaian storyboard video

(Rohman \& Mutmainah, 2015).

Analisis data hasil validasi media menggunakan skala likert.

$$
\text { Nilai kelayakan }=\frac{\text { Jumlah Skor }}{\text { Skor Kriterium }} \times 100 \%
$$

\section{HASIL DAN PEMBAHASAN}

\section{Tahap Analisis (Analysis)}

Tahap analisis ini merupakan tahap yang menggambarkan apa yang akan dipertimbangkan (Hadi \& Agustina, 2016).

a. Analisis Kebutuhan

Kegiatan dalam analisis kebutuhan adalah penyebaran angket analisis kebutuhan kepada mahasiswa. Hasil angket analisis kebutuhan menunjukkan bahwa mahasiswa tertarik dan membutuhkan video animasi struktur atom terintegrasi keislaman untuk bisa memahami lebih mudah mengenai materi struktur atom terintegrasi keislaman. Oleh karena itu, salah satu solusi yang dapat dilakukan adalah dengan mengembangkan video animasi kimia terintegrasi keislaman.

b. Merumuskan Tujuan Instruksional

Tujuan Instruksional didapatkan dari hasil analisis kebutuhan. Adapun hasil rumusan tujuan instruksional adalah mengembangkan video animasi dengan penjelasan yang menarik juga mengembangkan video animasi yang dapat 
membantu dalam pemahaman struktur atom terintegrasi keislaman.

c. Menentukan Materi

Materi yang dikembangkan dalam penelitian ini meliputi struktur atom terintegrasi keislaman. Materi struktur atom merupakan materi yang abstrak juga tidak bisa terlihat secara langsung dengan kasat mata. Oleh karena itu membutuhkan visualisasi berupa suatu penggambaran yang dapat membentuk imajinasi.

d. Analisis Konsep

Analisis konsep dilakukan dengan menganalisis karakteristik yang dimiliki konsep materi struktur atom. Analisis konsep ini meliputi label konsep, definisi konsep, jenis konsep, atribut (kritis dan variabel), posisi (Superordinat, koordinat, subordinat) serta contoh dan non contoh. Analisis konsep struktur atom yang telah dilakukan peneliti terdapat 11 konsep dari empat buku sumber referensi. Konsep yang dianalisis diantaranya atom, teori atom masa Yunani kuno, teori model atom Dalton, teori model atom Thompson, teori model atom Rutherford, teori model atom Niels Bohr, teori model atom mekanika kuantum, inti atom, proton, neutron dan elektron.

e. Struktur Makro

Hasil analisis konsep selanjutnya dibentuk dalam struktur makro atau peta konsep yang kemudian diintegrasikan keislamannya.

f. Integrasi Sains dan Islam

Konsep yang telah dipilih dalam analisis konsep diintegrasikan dengan keislaman. Hasil integrasi dilakukan validasi oleh ahli. Nilai CVR (Content Validity Ratio) yang didapat dari hasil validasi materi adalah sebesar 1 . Hasil CVR ini menunjukkan bahwa panel pakar (validator ahli) semuanya menyatakan sesuai untuk 11 pernyataan yang diberikan. Hal ini sejalan dengan (Lawshe, 1975) yang menjelaskan bahwa formula CVR menghasilkan nilai-nilai yang berkisar dari +1 sampai -1. Jika nilai CVR lebih besar dari 0 maka semakin tinggi validitas isinya. Hal ini menunjukkan bahwa terdapat kesesuaian dalam mengintegrasikan konsep struktur atom dengan keislaman.

\section{g. Kontruk Materi Terintegrasi}

Setelah integrasi konsep struktur atom dan keislaman dinyatakan valid oleh ahli, maka dibuatlah kontruk materi terintegrasi islam. Kontruk materi terintegrasi ini dituangkan dalam dalam bentuk video animasi menggunakan Microsoft powerpoint 2019.

\section{Tahap Perancangan (Design)}

a. Pembuatan Storyboard Video Animasi

Proses pembuatan storyboard video animasi dilakukan dengan merancang materi struktur atom terintegrasi keislaman yang telah divalidasi lalu mengubahnya dalam bentuk papan cerita atau alur cerita. Kemudian storyboard yang telah dirancang dijadikan panduan dalam proses pembuatan video animasi.

b. Validasi Storyboard Video Animasi

Storyboard video animasi yang telah selesai dirancang kemudian dilakukan validasi. Validasi ini dilakukan untuk mengetahui kesesuaian antara materi dengan alur cerita yang terstruktur dengan baik. Hal ini sesuai dengan yang ditulis oleh Azhar (2014) yang menjelaskan bahwa seluruh isi materi tercakup dalam storyboard dan harus disertai dengan pendahuluan yang menarik perhatian. Hasil validasi storyboard video 1 adalah 99,50\% dengan kriteria sangat layak, story board video 2 adalah 98,95\% dengan kriteria sangat layak dan storyboard video 3 adalah 98,6\% dengan kriteria sangat layak.

c. Revisi Storyboard Video Animasi

Proses validasi Storyboard yang telah dilakukan selain mendapat penilaian dari validator juga mendapat catatan. Catatan dari validator ini dijadikan masukan untuk melakukan revisi.

d. Validasi Instrumen Angket Respon Mahasiswa

Hasil validasi oleh ahli terhadap angket respon mahasiswa adalah layak untuk digunakan dengan presentase $100 \%$.

\section{Tahap Pengembangan (Development)}

Tahap Development ini adalah tahap pembuatan video animasi struktur atom terintegrasi keislaman. Proses pembuatan video animasi ini dilakukan dengan memanfaatkan fitur-fitur dalam 
Microsoft powerpoint 2019 yang didalamnya terdapat menu bar yang mendukung dalam proses pembuatan video animasi. Selain itu, dalam Microsoft powerpoint 2019 juga terdapat transisi antar slide yang menarik. Setelah semua alur cerita dalam storyboard dituangkan dalam powerpoint, peneliti mengatur waktu muncul dan hilangnya animasi pada setiap slide. Kemudian peneliti Mengexport powerpoint yang semula berbentuk slide menjadi bentuk video. Ketika sudah terbentuk video animasi, langkah selanjutnya adalah membuat rekaman suara untuk kebutuhan narasi dalam video. Tahap terakhir dalam pengembangan video animasi ini adalah menggabungkan video, rekaman suara, dan backsound serta menyesuaikan timing antara ketiganya menggunakan Adobe Premiere. Menurut Zaini \& Nugraha (2020) Adobe premiere merupakan aplikasi editing video yang digunakan untuk menghasilkan media audio visual. Setelah video animasi selesai dikembangkan, tahap selanjutnya adalah validasi video animasi oleh dosen ahli media. Hasil validasi menunjukkan presentase kelayakan video 1 sebesar $82,50 \%$, presentase kelayakan video 2 sebesar $83,75 \%$, presentase kelayakan video 3 sebesar $82,50 \%$. Hal ini menunjukkan bahwa ketiga video animasi yang telah dikembangkan memiliki kriteria sangat layak digunakan. Hal ini sejalan dengan teori menurut Damayanti et al., (2018) yang menyatakan bahwa suatu produk dikategorikan sangat layak jika $X$ > $81 \%$.

\section{Tahap Penerapan (Implementation)}

Tahap implementation atau penerapan dilakukan dengan kegiatan uji coba terbatas kepada mahasiswa pendidikan kimia. Uji coba terbatas dilakukan dengan mengirimkan link video animasi yang telah diupload ke google drive agar mahasiswa-mahasiswi bisa menonton video tersebut. Setelah itu mahasiswa diarahkan untuk mengisi angket respon mahasiswa terhadap video animasi yang telah ditonton. Data hasil angket respon mahasiswa dalam uji terbatas adalah $84,30 \%$ dengan kriteria sangat layak. Adapun aspek yang terdapat dalam uji terbatas ini diantaranya aspek minat terhadap media sebesar $84 \%$, aspek penguasaan materi sebesar $83,30 \%$, aspek integrasi sains dan islam sebesar $86,4 \%$, aspek tampilan sebesar $83 \%$, aspek keterlaksanaan sebesar $84,7 \%$ dan aspek audio sebesar $84,1 \%$.

\section{KESIMPULAN}

Berdasarkan hasil penelitian dan pembahasan, video animasi kimia terintegrasi keislaman pada materi struktur atom telah valid berdasarkan penilaian oleh ahli dengan presentase video 1 sebesar $82,50 \%$, presentase kelayakan video 2 sebesar $83,75 \%$, presentase kelayakan video 3 sebesar $82,50 \%$. Tahap Evaluasi bisa dilakukan oleh peneliti selanjutnya untuk melihat bagaimana keefektifan penggunaan video animasi kimia terintegrasi keislaman tersebut.

\section{UCAPAN TERIMA KASIH}

Terimakasih saya ucapkan kepada Bapak Buchori Muslim, M. Pd., dan Bapak Munasprianto Ramli, M.A., Ph. D., yang telah meluangkan waktu untuk memberikan bimbingan serta ilmu.

\section{DAFTAR PUSTAKA}

Al Farizi, Z., Sulisworo, D., Hasan, M. H., \& Rusdin, M. E. (2019). Pengembangan Media Animasi untuk Mendukung Pembelajaran Berbasis TPACK dengan POWTOON pada Materi Torsi SMA Kelas XI. Jurnal Penelitian Pembelajaran Fisika, 10(2), 108113.

Anggriani, N. Y. (2019). Pengembangan Media Pembelajaran Video Animasi Untuk Meningkatkan Kemampuan Berfikir Tingkat Tinggi Dan Hasil Belajar di Sekolah Dasar. JTPPm (Jurnal Teknologi Pendidikan Dan Pembelajaran): Edutech and Intructional Research Journal, 6(1).

Arifudin, I. (2017). Integrasi Sains dan Agama serta Implikasinya terhadap Pendidikan Islam. Edukasia Islamika, 161-180.

Arikunto, S. (2014). Metode penelitian kuantitatif, kualitatif, dan kombinasi (mixed methods). Bandung: Alfabeta.

Arsanti, M. (2018). Pengembangan bahan ajar mata kuliah penulisan kreatif bermuatan nilai-nilai pendidikan karakter religius bagi mahasiswa prodi PBSI, FKIP, UNISSULA. KREDO: Jurnal Ilmiah Bahasa Dan Sastra, 1(2), 6988. 
Azhar, A. (2014). Media Pembelajaran (Depok: PT Rajagrafindo Persada).

Brady, J. E. (1999). Kimia Universitas Asas \& Struktur Jilid 1. Edisi Ke5, Jakarta: Binarupa Aksara.

Damayanti, A. E., Syafei, I., Komikesari, H., \& Rahayu, R. (2018). Kelayakan Media Pembelajaran Fisika Berupa Buku Saku Berbasis Android Pada Materi Fluida Statis. Indonesian Journal of Science and Mathematics Education, 1(1), 63-70.

Ghalib, A. K. (2009). The True Power Of Atom. Diva Press.

Hadi, H., \& Agustina, S. (2016). Pengembangan buku ajar geografi desa-kota menggunakan model ADDIE. Jurnal Educatio, 11(1), 90105.

Kusuma, W. M., Sudira, P., Hasibuan, M. A., \& Daryono, R. W. (2021). The Perceptions of Vocational School Students of Video Animation-Based Learning Media to Operate Lathes in Distance Learning. Journal of Education Technology, 5(2).

Ladan, S. I. (2015). The relevance of studying astronomy in islamic universities of Nigeria with particular reference to Al-Qalam university, Katsina. European Scientific Journal, 11(5).

Lawshe, C. H. (1975). A quantitative approach to content validity. Personnel Psychology, 28(4), 563-575.

Mas'ud, H. A. (2020). Paradigma Pendidikan Islam Humanis. IRCISOD.

Rohman, M. A. (2015). Pengembangan Media Permainan Monopoli dalam Pelajaran Seni Budaya dan Keterampilan Kelas VI SDN Tanamera I. Jurnal Seni Rupa, 3(1).

Sabarni, S. (2019). Struktur Atom Berdasarkan Ilmu Kimia dan Perspektif Al-quran. Lantanida Journal, 7(1), 87-100.

Sakai, R. (2017). Analisis Efektifitas Jembatan Penyeberangan di Jalan S. Parman (Samping Mall Lembuswana) Samarinda. Kurva $S$ Jurnal Mahasiswa, 2(2), 314-325.

Suardika, I. K. (2016). Pengembangan Video Pembelajaran Kebugaran Jasmani Berlandaskan Tri Kaya Parisudha. Jurnal Pendidikan Kesehatan Rekreasi, 2(2), 93101.

Zaini, M. S., \& Nugraha, J. (2020). Pengembangan Media Pembelajaran Multimedia Interaktif Berbasis Adobe Premiere Pro Pada Kompetensi Dasar Mengelola Kegiatan Humas Kelas XI Administrasi Perkantoran di SMK Negeri 2 Buduran Sidorajo. Jurnal Pendidikan Administrasi Perkantoran (JPAP), 9(2), 349-361. 